\title{
Kajian Biblikal tentang Manusia Rohani dan Manusia Duniawi
}

\author{
Yonatan Alex Arifianto \\ Sekolah Tinggi Teologi Sangkakala, Salatiga \\ arifianto.alex@sttsangkakala.ac.id
}

\begin{abstract}
Immaturity in taking an attitude and acting as they should be following the way and order of God's Word can be called a worldly man who has the impact of jealousy, strife, so as to give rise to worldly people who do not know the truth. The natural man will also represent who the believer is. Spiritual maturity that involves God's role in the work of the Holy Spirit will continue to renew the mind and passion to continue fellowship with God. Likewise, what happens for humans who are in Jesus Christ will become a person in His image and become a blessing to others. With descriptive qualitative research methods, the author can describe the classification of the worldly man which refers to the immature in Christ, whose food is still limited to milk, and has an attitude of envy, strife and lives in a worldly manner. In addition, a spiritual person is described by the indicators: leaving childishness, accepting solid food and becoming a peacemaker, so that he can continue to grow, have a changed consciousness in all good things. In the end, the spiritual man can be a blessing and give good fruit to the lives of others.
\end{abstract}

Keywords: spiritual maturity; spiritual man; worldly man

\begin{abstract}
Abstrak: Ketidakdewasaan dalam mengambil sikap dan bertindak sebagaimana seharusnya mengikuti cara dan tatanan Firman Tuhan dapat disebut sebagai manusia duniawi yang memiliki dampak iri hati, perselisihan sehingga memunculkan manusia duniawi yang tidak mengenal kebenaran. Manusia duniawi itu juga akan mepresentasikan siapa pribadi orang percaya. Kedewasaan rohani yang melibatkan peran Tuhan dalam karya Roh Kudus akan terus memperbaharui pikiran dan gairah untuk terus bersekutu dengan Tuhan. Demikianlah juga yang terjadi bagi manusia yang ada dalam Yesus Kristus akan menjadi pribadi yang serupa dengan gambarNya dan menjadi berkat bagi sesama. Dengan metode penelitian kualitatif deskriptif, penulis dapat mendeskripsikan klasifikasi manusia duniawi yang mengacu pada belum dewasa dalam Kristus, yang makanannya masih sebatas susu, serta memiliki sikap iri hati, perselisihan dan hidup secara duniawi. Selain itu, dideskripsikan manusia rohani dengan indikator: meninggalkan sifat kanak-kanak, menerima makanan keras dan menjadi pembawa damai, sehingga dapat terus bertumbuh, memiliki kesadaran berubah dalam segala hal yang baik. Pada akhirnya manusia rohani dapat menjadi berkat dan memberikan buah yang baik bagi kehidupan orang lain.
\end{abstract}

Kata kunci: dewasa rohani; manusia duniawi; manusia rohani

\section{Pendahuluan}

Allah menciptakan manusia menurut rupa dan gambarNya (Kej. 1:26-27). Penciptaan manusia ini mengangkat manusia sebagai karya ciptaan Allah yang terbesar karena manusia adalah satu-satunya ciptaan yang dapat memiliki hubungan serta persekutuan dengan Allah Pencipta. ${ }^{1}$ Dalam perjalanannya manusia jatuh ke dalam dosa, yang membawa kesengsaran hingga kepada keturunan berikutnya. Dosa hasil dari godaan iblis yang memutarbalikkan fakta dan membuat wanita atau Hawa menyerah lalu membujuk

${ }^{1}$ Donald Guthrie, Teologi Perjanjian Baru 1 (Jakarta: BPK Gunung Mulia, 2008), 104. 
suaminya Adam hingga akhirnya bersama-sama melanggar larangan yang ditetapkan dalam perjanjian di taman Eden. ${ }^{2}$ Allah menciptakan manusia dengan predikat baik keadaannya sebab manusia diciptakan Allah adalah gambar yang sakral yang diberi kapasitas secara unik untuk mencerminkan dan merefleksikan karakter Allah. ${ }^{3}$

Sosa merupakan akibat dari kesombongan malaikat yang hendak menyamai Yang Maha Tinggi. Nabi Yesaya menggambarkan jatuhnya malaikat dari surga yang bernama "Lucifer" dalam versi alkitab terjemahan King James dan dijuluki "Bintang Timur, Putera Fajar" dalam Alkitab terjemahan baru (Yes. 14:12-18). Malaikat yang jatuh itu menawarkan pemberontakan dan ketidak patuhan terhadap Allah pencipta kepada manusia dibungkus dengan kebohongan atau jebakan iblis dalam memutar balikkan fakta kebenaran yang sebenarnya. Istilah kejatuhan manusia dalam dosa awal mula ini membuat Paulus mengungkapkan bahwa manusia telah berdosa dan telah kehilangan kemuliaan Allah. (Rm. 3:23). Manusia mengalami dampak yang berat seperti yang ditulis kitab Kejadian. Akibatnya dampak dosa merusak gambar Allah dan karakter Allah yang ditanamkan dalam diri manusia sehingga manusia memberontak terhadap Allah. ${ }^{4}$ Namun manusia yang memiliki hubungan persekutuan dengan Tuhan yang terputus dapat kembali terhubung ketika mereka percaya kepada Yesus yang adalah Tuhan dan juruselamat manusia. Menggenapi apa yang Allah firmankan menutup dosa atau pendamaian untuk dosa tidak mungkin dilakukan oleh tangan manusia ${ }^{5}$, dan keselamatan atau pengembalian manusia harus Allah yang melakukan tugas pengembalian kemuliaan dan hubungan kembali kepada Tuhan.

Pada kenyataannya secara kasat mata terlihat bahwa manusia tidak mempedulikan kasih karunia Allah dalam Yesus Kristus dan memilih menolak keselamatam yang diberikan secara gratis. Kenyataan ini memberikan predikat baru bagi manusia yang tidak menerima pemberian Allah adalah manusia duniawi. Manusia duniawi ini tidak bisa menerima dengan akal maupun iman hal-hal yang disingkapkan oleh Allah, karena baginya itu tidak masuk akal. Akibatnya, manusia duniawi tidak bisa memahami dan memiliki pengertian hal-hal secara rohani yang dinyatakan dalam hidupnya. Sebaliknya, manusia rohani memiliki kecenderungan untuk berusaha memiliki pikiran Kristus, serta dapat bersinergi dalam membangun hubungan dengan Penciptannya. Manusia rohani juga dapat menilai segala sesuatu dan dapat memahami serta dapat menerima apa yang berasal dari Allah (1 Kor. 2:14-15). Karena semakin memiliki manusia rohani semakin bijaksana dalam berpikir. Tujuan dalam penelitian ini adalah untuk membandingkan antara manusia duniawi dan rohani dengan menggunakan pendekatan deskripsi nas pada 1 Korintus 3:1-4.

\section{Metode Penelitian}

Penelitian ini merupakan kajian deskriptif atas nas 1 Korintus 3:1-4, yang memberikan gambaran tentang manusia rohani dan duniawi. Pendekatan kualitatif literatur atau studi

\footnotetext{
${ }^{2}$ Zuck Roy B., A Biblical Teologi Of The Old Testament (Malang: Gandum Mas, 2015), 45.

${ }^{3}$ R.C. Sproul, Kebenaran-Kebenaran Dasar Iman Kristen (Malang: Literatur SAAT, 2018), 171.

${ }^{4}$ Bruce Milne, Mengenal Kebenaran (Jakarta: BPK Gunung Mulia, 2009), 146.

${ }^{5}$ Bruce Wilkinson and Boa Kenneth, Talk Thru The Bible (Malang: Gandum Mas, 2017), 14.
} 
pustaka digunakan dalam penelitian ini $^{6}$ untuk memperolah data deskriptif tentang pokok bahasan, yang selanjutnya dipahami dengan pendekatan hermeneutis. Penulis mengkaji penelitian pustaka dengan pendekatan kualitatif deskritif, dengan menggunakan Alkitab sebagai sumber primer dalam mengkaji dan menganalisis penelitian ini. Penulis juga melakukan kajian terhadap sumber-sumber literatur dan menguraikannya dalam sebuah kerangka uraian sehingga lebih mudah dipahami. Penulis menggunakan sumber-sumber acuan dan rujukan yang dapat melengkapi penelitian ini yang masih dianggap menjadi sumber penunjang. Penulis serta merta menggunakan beberapa sumber tambahan dari buku-buku yang membahas tentang manusia rohani dan manusia duniawi, namun penulis juga menggunakan sumber tambahan dari berbagai sumber jurnal sehingga sumber sumber literatur tersebut diolah menjadi rangkaian analisis yang dapat di deskripsikan mengikuti prinsip literatur review yang dimaksud oleh Denney. ${ }^{7}$ Penulis menganalisis melalui perbandingan antara manusia rohani dan manusia duniawi dalam kerangka Alkitab.

\section{Pembahasan}

Manusia adalah makluk yang memiliki kelebihan yang sangat dominan dari makluk yang diciptakan Tuhan lainnya di dunia ini. Manusia yang dijadikan dengan tangan dan nafas Allah adalah ciptaan yang sempurna dengan segala kelebihannya; bahkan Alkitab menyatakan manusia diciptakan sesuai atau menurut gambar dan rupa Allah (Kej 1: 26-27). Firman Tuhan juga menjelaskan bahwa hidup manusia terdiri dari tiga bagian roh, jiwa dan tubuh (1 Tes. 5:23). Pandangan yang disampaikan oleh rasul Paulus ini memberi pengertian bahwa Allah menciptakan manusia dengan memberikan tiga unsur utama di dalam diri manusia yang adalah satu kesatuan dalam manusia hidup. ${ }^{8}$

Bagian yang kelihatan secara fisik dan kasat mata dari luar adalah tubuh (jasmani, lahiriah), tetapi di dalam tubuh sejatinya juga terdapat jiwa dan roh. Jiwa terdiri dari pikiran, perasaan dan kehendak. Dan yang paling utama dan inti dari manusia adalah roh. Yang dimana roh itu dapat bersekutu dengan Tuhan dan manusia roh ini adalah nafas Allah yang dihembuskan saat penciptaan manusia. Roh adalah prinsip kehidupan manusia, karena roh adalah sifat alami manusia yang immaterial yang memungkinkan manusia berkomunikasi dengan Tuhan yang juga adalah Roh. ${ }^{9}$ Tetapi bukan saja manusia secara daging atau tubuh yang dibahas dalam paper ini melainkan manusia duniawi yang tidak dapat bekerja sama dengan Tuhan dalam memahami pikiran dan rencana Tuhan namun juga sebaliknya.

${ }^{6}$ Sonny Eli Zaluchu, "Strategi Penelitian Kualitatif Dan Kuantitatif Di Dalam Penelitian Agama," Evangelikal: Jurnal Teologi Injili Dan Pembinaan Warga Jemaat, 2020, https://doi.org/10.46445/ejti.v4i1.167.

${ }^{7}$ Andrew S. Denney and Richard Tewksbury, "How to Write a Literature Review," Journal of Criminal Justice Education 24, no. 2 (2013): 218-34, https://doi.org/10.1080/10511253.2012.730617.

${ }^{8}$ Djohan Gunawan, Roh Inspirasi Anda Agar Hidup Dan Usaha Lebih Sukses (Jakarta: Elex Media Komputindo, 2014), 12-13.

${ }^{9}$ Gunawan, Roh Inspirasi Anda Agar Hidup Dan Usaha Lebih Sukses. 


\section{Karakteristik Manusia Duniawi}

Dalam 1 Korintus 3:1-4 kata yang digunakan oleh Paulus dalam mengistilahkan manusia duniawi ada dua macam, dan memiliki sifat dan arti berbeda. Kata pertama adalah

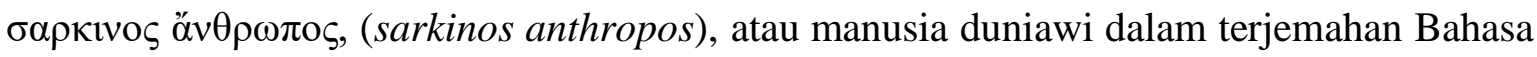
Indonesia (1Kor. 3:1) memiliki maksud dan arti yang terdiri dari daging, lemah, duniawi. ${ }^{10}$ Sehingga Paulus menyatakan jemaat Korintus belum dewasa masih seperti anak-anak yang

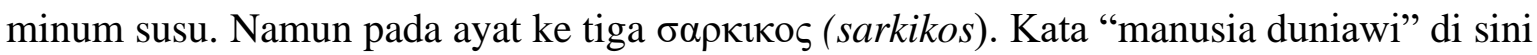
bukan sarkinos tetapi sarkikos, yang secara harfiah artinya bersifat seperti daging, yang sama artinya dengan menuruti keinginan daging. Kata ini digunakan sebagi teguran karena pada kenyataannya jemaat Korintus tidak sesuai dengan gambaran yang diharapkan dalam jemaat Tuhan; mereka masih memiliki sifat iri dan perselisihan. ${ }^{11}$ Beberapa hal dapat dilihat sebagai karakteristik, atau yang mencirikan manusia duniawi sesuai bingkai deskriptif 1 Korintus 3:1-4

\section{Belum Dewasa dalam Kristus}

Paulus menyebutkan karakteristik pertama dalam ayat ini adalah, belum dewasa dalam Kristus (1 Kor. 3:1). Istilah ini dalam bahasa Yunani nepios, yang memiliki arti kanakkanak, belum dewasa, anak kecil. V.C Pfitzner mengemukakan bahwa: Manusia duniawi adalah manusia dalam sifat dan pemikiran, tidak tersentuh dan tidak terdidik oleh Roh Allah dan masih berada di bawah kuasa dosa (Rom. 7:14). ${ }^{12}$ Hal tersebut di karenakan dalam proses kerohanian masih memiliki pola pikir anak-anak. Orang percaya seharusnya menjadi manusia rohani dan tidak boleh menjadi manusia duniawi. ${ }^{13}$ Perbedaan sikap dan karakter inilah yang ditampilkan sebagai prilaku manusia dalam menjalani hidup.

Perilaku yang tidak sesuai dengan Firman Tuhan yang ditonjolkan sebagai kepribadian manusia duniawi dan memiliki ciri manusia yang masih suka akan kesenangan dunia yang ditawarkan. Hal itu dikarenakan memiliki pikiran yang dikuasai keinginan daging yang menghasilkan pemberontakan melawan pemerintahan dan kehendak Allah. ${ }^{14}$ Karena kehidupan rohani inilah yang dapat menentukan bagaimana seseorang dapat disebut manusia rohani. Paulus menegur jemaat Korintus yang masih bersikap duniawi, yaitu mereka yang belum bertumbuh dapat dikatakan belum dewasa dalam Kristus (1Kor. 3:1). Manusia duniawi tidak mampu menyambut dan menyenangkan Allah. Hal itu dikarenakan pola pikir dan tindakan dalam menjalani kehidupan kekristenannya masih seperti kanak-kanak (1 Kor. 14:20).

Kekristenan yang identik dengan perubahan hidup dan juga memiliki tujuan pertumbuhan kerohanian yang terus-menerus setiap hari dikerjakan. Tanpa perubahan

\footnotetext{
${ }^{10}$ B.F. Drewes, Wilfrid Haubeck, and Siebenthal Heinrich Von, Kunci Bahasa Yunani Perjanjian Baru Surat Roma Hingga Kitab Wahyu, (Jakarta: BPK Gunung Mulia, 2011), 59.

${ }^{11}$ Drewes, Haubeck, and Von, Kunci Bahasa Yunani Perjanjian Baru Surat Roma Hingga Kitab Wahyu, 2006), 50.

${ }^{12}$ V.C Pfitzner, Kesatuan Dalam Kepelbagaian : Ulasan Atas 1 Korintus (Malang: Gandum Mas,

${ }^{13}$ Dag Heward, Pengaruh Manis Dari Pengurapan (mill, 2018), 34.

${ }^{14}$ John Piper, Sukacita Ekspositori (Surabaya: Literatur Perkantas, 2020), 199-120.
} 
hidup maka kekristenan hanya sebuah retorika. Seperti yang diungkapkan Rasul Paulus menyebut orang percaya di Korintus adalah pribadi yang digambarkan manusia yang belum dewasa dalam kehidupan kekristen karena mereka masih belum bertumbuh dan belum dewasa secara rohani. ${ }^{15}$ Orang Percaya harus sungguh-sungguh mau diubahkan dan harus berani mempertaruhkan seluruh hidupnya untuk proses perubahan. ${ }^{16}$ Namun orang percaya dapat saja terjebak dalam kegiatan rohani seperti melayani Allah dalam bentuk melayani diakonia, memberitakan Injil, pelayanan didaskalia.

Pelayanan yang dilakukan harus sejalan dengan kehidupan rohani yang dapat membawa pertumbuhan dan kematangan dalam mengikut Tuhan. Supaya kerohanian yang sehat terlebih kerohanian yang memberi dampak buah untuk dinikmati orang lain. Namun bila tidak Pelaksanaan ibadah orang percaya yang dilakukan dapat dikatakan tidak berkenan di hadapan Allah. Hal ini disebabkan karena apa yang dilakukan umat dalam kehidupan keagamaannya tidak benar di dalam pandangan Allah. ${ }^{17}$ Menurut Rifai ketidakdewasaan rohani diartikan bahwa setiap orang yang tidak memiliki pengetahuan akan kebenaran iman Kristen. Dan akibat dari kurangnya pengajaran dan pemahaman akan firman Tuhan serta kerinduan, lapar dan haus orang percaya akan firman Tuhan tidak menjadi prioritas hidup. Walaupun kehidupan mereka dalam keseharian di Korintus merasa sudah dekat dengan para Rasul. Ketidakdewasaan rohani dapat mengakibatkan orang tidak menjadi pelaku Firman; hal itu menggambarkan orang yang tidak memahami ajaran tentang kebenaran. Berbanding terbalik dengan orang yang tekun dalam pengajaran Firman Tuhan, maka pengajaran itu harus diwujudkan dalam perbuatannya. ${ }^{18}$

\section{Makanannya masih Sebatas yang Lembut}

Manusia bertumbuh dari bayi sampai dewasa; itulah proses dan tahapan pertumbuhan,di mana membutuhkan makanan yang sesuai. Waktu bayi, diberikan air susu, dan semakin besar proses pertumbuhan jasmaninya, diberikanlah makanan agak keras, dan ketika telah dewasa diberikan makanan keras. Hal itu menunjukan kedewasaan yang terihat dari perubahan fisik. Didalam kerohanian memang umur tidak menentukan kedewasaan rohani, seberapa lama orang percaya menjadi orang Kristen tidak dapat mewakili iman dan kerohaniannya. Namun hubungan pribadi dengan Tuhan dan cara menghadapi proses kehidupan akan terlihat kedewasaannya dalam menghadapi persoalan seperti yang terjadi di jemaat Korintus adanya perbedaan pendapat dan golongan. Dalam arti luas dapat diterjemahakan bahwa manusia yang hidupnya ada pada rendahnya kemampuan kerohanian manusia dalam membangun dan terhubung dengan Tuhan. Dapat juga diartikan bahwa manusia duniawi (sarkinos anthropos) adalah manusia yang tidak dapat menerima hal-hal supranatural maupun natural yang berasal dari Roh Allah, karena bagi mereka hal-hal

\footnotetext{
${ }^{15}$ Donald c. Stamp, Alkitab Hidup Berkelimpahan (Malang: gandum mas, 1994).

${ }^{16}$ Erastus Sabdono, Tanggung Jawab Memiliki Keselamatan (Jakarta: Rehobat Literatur, 2020), 86.

${ }^{17}$ M E Yanti, "Integritas Dalam Peribadatan Menurut Amos 4: 4-5," IMMANUEL: Jurnal Teologi Dan Pendidikan Kristen,1. no 1,(2020) 1-17.

${ }^{18}$ Orles, "Efektifitas Pemuridan KEKAL Dalam Membimbing Gereja Menuju Kedewasaan Rohani," HUPEERETÉS Jurnal Teologi Dan Pendidikan Kristen 1, no. 2 (2020): 118-29.
} 
tersebut adalah kebodohan dan tidak berarti bagi tubuh jasmaniah serta manusia duniawi. Semua hal itu tidak dapat dipahami, namun hanya bisa dinilai secara rohani (1 Kor. 2:14).

Dalam Ibrani 5:13 diungkapkan bahwa barangsiapa masih memerlukan susu ia tidak memahami ajaran tentang kebenaran, sebab ia adalah anak kecil. Penulis Ibrani melengkapi kriteria manusia dunia yang tidak bisa menerima ajaran yang keras yang dapat membawa pada kedewasaan, namun hanya mampu menerima pengajaran yang menyenangkan telinga. Ketidakmauannya diajar dengan Firman yang membawa pada kedewasaan, maka manusia duniawi tidak hidup seturut dengan kehendak dan tujuan Roh Allah sehingga pertumbuhan yang layaknya harus diterima menjadi kerdil dan tidak bertumbuh sekalipun.

Paulus dalam tulisannya juga menghimbau dan menasihati jemaat di Korintus tentang tidak dewasanya kerohanian mereka. Yang digambarkan hanya susu sebagai makanan yang baik dan layak dikomsumsi oleh bayi dan bukan makanan yang keras. Dikarenakan belum bisa diterima oleh akal dan pikiran yang masih anak-anak. Sehingga ketidakdewasaan rohani dapat juga disebut kanak-kanak rohani. Paulus juga mendeskripsikan bagaimana dampak dari kelakuan dan tindakan mereka yakni menuruti hawa nafsu mereka saja yang mau dipuaskan oleh ajaran-ajaran yang menyenangkan pendengaran saja tanpa adanya proses kedewasaan dalam memakan makanan rohani yang keras sebagai wujud kedewasaan rohani. Pada inti dan nilai kebenarannya mereka tidak memberikan dirinya dalam pengenalan akan Allah di dalam segala aspek kehidupannya.

Inilah penyebab mereka tidak menerima hal-hal yang bersifat rohani yang berasal dari Allah sebagai bagian persekutuan dengan Tuhan. Sehingga seluruh kehidupan mereka dan seluruh sikap hati mereka menolak pengajaran terlebih mereka tidak menjadikan Yesus sebagai pribadi yang membawa pada keselamatan kekal. Manusia duniawi ini juga menganggap Kristus adalah kebodohan dan menyatakan itu bukan hikmat dari Allah. Pernyataan Paulus kepada jemaat Korintus adalah pernyataan yang menegur dengan keras karena tidak adanya pertumbuhan kerohanian dan Paulus mengakui mereka masih belum hidup dipimpin oleh Roh Allah. Karena sejatinya Roh Allah yang siap memimpin dan menuntun ke dalam ketaatan baik secara pribadi atau individu juga Ia menuntun orang percaya kepada seluruh kebenaran. ${ }^{19}$ Peran Roh Kudus juga mutlak diperlukan dalam memelihara ajaran dan kesaksian yang terpusat pada Yesus. ${ }^{20}$

Manusia yang hanya memikirkan diri sendiri dan pola pikir yang cenderung sebagai pribadi kekanak-kanakan terlebih tidak memiliki hubungan yang dengan Tuhan menjadi acuan penting sehingga Paulus membedakan penyebutan dari sarkinos dalam ayat satu menjadi sarkikos pada ayat tiga; sarkinos adalah bayi di dalam Kristus, sedangkan sarkikos adalah orang Kristen yang sudah lama menjadi Kristen tetapi belum dewasa. Orang tersebut dapat disamakan sebagaimana bayi yang selalu mengharapkan perhatian dari orangorang yang di sekitarnya, demikian halnya dengan orang Kristen yang tidak dewasa juga

\footnotetext{
${ }^{19}$ Erastus Sabdono, Makna Sejati Pentakosta (Jakarta: Literatur Perkantas, 2019), 11.

${ }^{20}$ Yonatan Alex Arifianto and Asih sumiwi Rachmani, "Peran Roh Kudus Dalam Menuntun Orang Percaya Kepada Seluruh Kebenaran Berdasarkan Yohanes 16 : 13,” Jurnal Diegesis 3, no. 1 (2020): 1-12.
} 
selalu menuntut perhatian dari orang lain dalam gereja. Apabila ia tidak mendapatkan apa yang diinginkan dari orang lain di dalam gereja maka ia akan marah dan membuat ulah di dalam gereja. ${ }^{21}$ Sehingga akhirnya bersikap apatis terhadap pelayanan, mereka tidak mau peduli dengan pekerjaan Tuhan. Padahal orang percaya dan gereja sebagai tubuh Kristus, dipanggil dan ditempatkan di tengah-tengah dunia untuk bertumbuh dan berkembang. Pertumbuhan dan perkembangan gereja yang didalamnya orang percaya sebagai bagian dari kesatuan gereja merupakan suatu keharusan. sehingga rencana-rencana dan programprogram gereja dapat berjalan dengan baik dikerjakan untuk memuliakan Tuhan. ${ }^{22}$

\section{Memiliki Sikap Iri Hati, Perselisihan dan hidup secara duniawi.}

Iri hati dapat mempengaruhi seluruh kehidupan manusia sehingga menimbulkan perselisihan. Seperti juga yang dinyatakan oleh penulis kitab Yudas "mereka menuruti hawa nafsu, pemecah belah, dan dikuasi oleh keinginan-keinginan duniawi. Sama seperti jemaat Korintus tentang mengunggulkan manusia akhirnya mereka terpecah belah hanya karena manusia" (Yud. 1:18-19). Paulus juga menyatakan kepada mereka bagaimana manusia duniawi tidak memiliki hikmat Tuhan sehingga tindakan seperti tindakan orang yang tidak mengenal kebenaran. Hikmat yang mereka gunakan adalah hikmat dari dunia, nafsu, dan setan-setan seperti yang diungkapakan oleh (Yak. 3:15). Frasa sarkikos anthropos juga dapat diartikan sebagai manusia hidup dalam kecemaran dan kedagingan atau manusia duniawi yang hidupnya ada pada level kedagingan yakni dikuasai nafsu dan dosa serta amarah. Karena mereka manusia duniawi tidak bisa mengerti firman Kristus (Yoh. 8:43). Hikmat duniawi mereka yang ditinggikan dan mendapat tempat teratas dalam hidupnya adalah kebodohan bagi Allah (1 Kor. 1:20; 3:19) sebab mereka menolak Kristus yang adalah kekuatan dan hikmat Allah (1 Korintus 1:23-24).

Sifat yang menonjol dalam jemaat Korintus adalah ketidakdewasaannya, yang mana terlihat pada perbedaan yang masih dikuasai oleh jiwa persaingan lama yang penuh dosa, sombong, dan egois yang berdampak pada perseteruan, perselisiahan, iri hati, amarah, kepentingan diri sendiri, percideraan, dan roh pemecah yang seperti Paulus ungkapkan dalam kitab Galatia (Gal. 5:20). Paulus dengan peringatan keras mengecam ketidakdewasaan hidup mereka. Perbuatan yang mencerminkan sifat dari ketidak dewasaan itu terjadi yakni pada saat terjadi klaim pemimpin rohani yang diidolakan jemaat. Keadaan yang menonjolkan pemimpin manusia dan membawa skat-skat perpisahan dapat mengakibkan terjadinya perpecahan jemaat karena mereka berusaha membandingkan antara rasul yang satu dengan rasul yang lainnya, sehingga akhirnya terjadi iri hati, dengki dan perselisihan; jauh dari tabiat seperti Kristus. ${ }^{23}$ Karena masih belum dewasa atau masih bayi-bayi rohani.

Hal ini membuktikan bahwa jemaat Korintus adalah jemaat yang merasa diri sudah dewasa, merasa dekat dengan para rasul, namun sejatinya mereka tidak memiliki manusia

\footnotetext{
${ }^{21}$ Agung Gunawan, "Pemuridan Dan Kedewasaan Rohani," Jurnal Theologia Aletheia, 2017.

${ }^{22}$ Arozatulo Telaumbanua, "Peran Gembala Sidang Sebagai Pendidik Dalam Pertumbuhan Rohani Jemaat," FIDEI: Jurnal Teologi Sistematika Dan Praktika, 2019, https://doi.org/10.34081/fidei.v2i2.45.

${ }^{23}$ Jerry White, Kejujuran, Moral Dan Hati Nurani (Jakarta: BPK Gunung Mulia, 2004), 146.
} 
rohani disebabkan adanya perselisihan, iri hati dan segala yang jahat seperti manusia yang tidak memiliki Roh Allah. Mengira diri manusia rohani dengan bermacam-macam karunia yang mereka miliki, tapi pada dasarnya mereka adalah manusia sarkikos, yaitu manusia yang tidak dapat diajar dan tidak mau bertumbuh dalam pengenalan akan Tuhan dan pimpinan Roh Kudus. Seharusnya dengan adanya kebenaran Alkitab maka orang dapat melihat dan mengenali sendiri berdasarkan kebenaran yang hakiki. ${ }^{24}$ Sebab roh perpecahan bekerja berdasarkan asas-asas manusiawi. Paulus melakukan koreksi dan peringatan kepada jemaat Korintus dan juga peringatan bagi orang percaya masa kini. Bahwa mereka yang belum dewasa cenderung untuk memisahkan diri, lebih penting, merasa eksklusif dan tidak dapat bersekutu erat dengan saudara seiman lainnya.

Menjauhi iri hati dan perselisihan harus menjauhkan untuk mengidolakan orang secara sepihak dan mengklaim idolanya yang paling benar walaupun yang menjadi panutan seperti Paulus, Apolos dan Petrus. Tetapi kenyataannya idola telah menimbulkan perselisihan dan kebanggan yang palsu diantara jemaat. Sebab kedewasaan rohani seorang Kristen dapat ditentukan dari sikapnya dalam menjalani kehidupan dengan sesama. Jika masih ada iri hati dan perselisihan, saling menjatuhkan dan menyombongkan pemimpinnya, sebenarnya ia belum dewasa dalam Kristus. Karena hal itu suatu kesombongan yang mengultuskan manusia dan menganggap apa yang diidolakan dapat membawa pada nilai kekal. Dan ini tidak sejalan dengan pemikiran Allah bahwa mereka yang mengidolakan para rasul dan segala apa yang telah dilakukan rasul bukanlah hikmat dan kepandaian para rasul melaikan kebenaran Allah atau Injil yang harus dipahami secara rohani. ${ }^{25}$

Daulany mengungkapkan bahwa penyebab perselisihan gereja adalah ketidakdewasaan anggotanya. ${ }^{26}$ Yakobus juga menyatakan bahwa kekacauan seperti perselisihan dan perpecahan adalah akibat dari adanya iri hati. Sebab di mana ada iri hati dan mementingkan diri sendiri di situ ada kekacauan dan segala macam perbuatan jahat (Yak. 3:16). Manusia duniawi diperintah oleh naluri alamiahnya, diperbudak dan diintervensi oleh kedagingan serta hawa nafsunya yang berada di bawah kendali kuasa iblis. Manusia duniawi ini menjadi sahabat dunia terlebih manusia duniawi tidak akan mendapat bagian sebagai anggota keluarga kerajaan Allah. ${ }^{27}$ Paulus memberikan teguran dan peringatan supaya orang kristen tidak melepaskan kewajiban-kewajiban moral dan juga harus menjalankan supaya tidak ada bahaya kedurhakaan. ${ }^{28}$ Kualitas iman itu sendiri dapat nampak dari penguasaan diri, yaitu dengan mengampuni orang yang bersalah dan meremehkan kehidupan. ${ }^{29}$

\footnotetext{
${ }^{24}$ Maria Wijiati, “Konseling Patoral Sebagai Sarana Dalam Membentuk Keluarga Kristen Masa Kini," Pneumatikos 6, no. 1 (2018): 2-55.

${ }^{25}$ Wilkinson and Kenneth, Talk Thru The Bible.

${ }^{26}$ Richard Daulany and Rahel Daulany, Firman Hidup 70 (Jakarta: BPK Gunung Mulia, 2008), 66.

${ }^{27}$ Sabdono, Tanggung Jawab Memiliki Keselamatan.

${ }^{28}$ John Drane, Mamahami Perjanjian Baru Pengantar Historis Teologis (Jakarta: BPK Gunung Mulia, 2016), 351.

${ }^{29}$ Jundo Parasian Siregar, "Pengembangan Watak Kristen Melalui Pengampunan," Imanuel Jurnal Teologi Dan Pendidikan Kristen 1, no. 1 (2020): 33-43.
} 


\section{Manusia Rohani dalam Yesus Kristus}

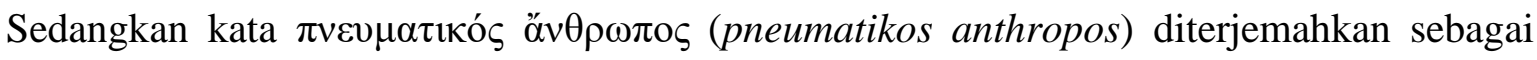
'manusia rohani' dalam Alkitab terjemahan Bahasa Indonesia (1 Kor. 3:1). Diartikan sebagai orang yang dipenuhi dengan Roh dan hidup dipimpin oleh Roh. Dewasa dalam kerohanian bukanlah perihal pertumbuhan fisik semata. Kedewasaan seseorang juga tidak ditentukan berdasarkan usia dan memiliki rentang waktu lama dalam mengiring Tuhan. Meski umur bertambah dan predikat tua disandang, belum tentu cara pikir juga bertambah matang. Di sisi lain, tidak sedikit ada orang berusia muda yang menunjukkan kedewasaan dan matang dalam menajalani kehidupan baik dalam berpikir, bertindak, dan mengambil keputusan. Pernyataan Paulus kepada Timotius memberikan makna baru bahwa apa yang disebut dengan manusia rohani adalah mereka yang melakukan kehendak Allah, hidup beribadat dan senantiasa percaya kepada Yesus, tabah dalam menghadapai segala perkara dan terlebih penting ramah dan lemah lembut kepada sesama (1 Tim. 6:11). Definisi manusia rohani adalah sikap hidup yang mengantungkan diri kepada Allah serta memiliki pengenalan akan Kristus sebagai bagian dari keinginan Tuhan untuk memimpin orang percaya terus menjadi berkat. Karena manusia rohani adalah manusia yang masih memiliki tubuh dan jiwa namun karakter dan sifat seperti Yesus yang menjadi nilai penting dalam predikat itu.

Watchman Nee, menyatakan bahwa manusia rohani juga memiliki pikiran, namun saja kini pikirannya tidak liar tetapi pikirannya di tuntun oleh Tuhan. ${ }^{30}$ Manusia rohani juga adalah manusia dalam proses menjadi manusia baru yang terus menerus diperbaharuhi untuk memperoleh pengetahuan yang benar menurut gambar penciptanya yaitu Allah. ${ }^{31}$ Sehingga membawa kedewasaan rohani dapat diterapkan dalam kehidupan orang percaya untuk terus berpegang teguh kepada kebenaran dan terus bertumbuh di dalam segala hal ke arah Dia, Kristus, yang adalah Kepala (Ef. 4:15). Sebab ukuran Pertumbuhan rohani terlihat dari relasi orang percaya dengan Yesus Kristus yang mana Imannya terus diproses. Sebab iman sejati akan terus bertahan di dalam penderitaan dan kesengsaraan, di tengahtengah berbagai pencobaan dan tawaran kenikmatan dunia yang menggoda. ${ }^{32}$ Senada dengan apa yang disampaikan Stephen Tong, Erastus Sabdono menekankan bahwa gairah orang percaya yang dikerjakan oleh Roh Kudus membuat orang yang didalam kristus Yesus adalah orang yang memiliki gairah, spirit dan hasrat seperti yang ada pada Yesus sehingga prilaku menjadi manusia rohani sama seperti prilaku Yesus. ${ }^{33}$

\section{Meninggalkan Sifat Kanak-kanak}

Kedewasaan rohani juga dapat dikerjakan dengan membuang sifat kekanak-kanakan. Yang sejatinya kekanak-kanakan itu hanya memerlukan makanan lembut dan susu namun tidak bisa menerima makanan keras. Karena kedewasaan rohani dalam pertumbuhannya sangat diharapkan sebagai orang yang percaya kepada Yesus dengan segala kedewasaannya.

\footnotetext{
${ }^{30}$ Watchman Nee, Manusia Rohani 2 (Surabaya: Yasperin, 2019), 34.

${ }^{31}$ Harun Hadiwijono, Iman Kristen (Jakarta: BPK Gunung Mulia, 1992), 26.

${ }^{32}$ Stephen Tong, From Faith To Faith, Dari Iman Kepada Iman (Surabaya: Momentum, 2013), 54.

${ }^{33}$ Sabdono, Makna Sejati Pentakosta, 129.
} 
Paulus juga memberikan pengertian kepada jemaat korintus supaya meninggalkan sifat kekanak-kanakan dan pola pikirnya. Rasul Paulus mengatakan: "Ketika aku kanak-kanak, aku berkata-kata seperti kanak-kanak, aku merasa seperti kanak-kanak, aku berpikir seperti kanak-kanak. Sekarang sesudah aku menjadi dewasa, aku meninggalkan sifat kanak-kanak itu" (1 Kor. 13:11).

Merujuk kepada jemaat Tuhan yang ada di kota Korintus, Paulus memberikan pengertian bahwa sesungguhnya ketika sudah lama menjadi pengikut Kristus atau menjadi orang Kristen tidak menjadi jaminan bahwa seseorang memiliki kehidupan rohani yang bertumbuh dan menghasilkan buah, karena ada banyak orang Kristen yang kualitas hidupnya tidak jauh berbeda dengan orang-orang di luar Tuhan, sehingga hidupnya bukannya menjadi berkat bagi orang lain tapi menjadi batu sandungan dan cacian terhadap kekristenan. Dan seharusnya orang percaya sebagai manusia rohani tidak memberikan kesempatan kodrat dosanya hidup, sebaliknya mematikan kodrat dosa digantikan dengan kodrat ilahi. ${ }^{34}$ Supaya pikirannya menjadi mengenal kebenaran dan membawa pikiran itu untuk tunduk dan takluk kepada otoritas firman Tuhan. Karena kebenaran Frman itu yang memperbaharui pikiran. ${ }^{35}$ Seperti yang diingkan Paulus kepada jemaat di Roma, "Janganlah kamu menjadi serupa dengan dunia ini, tetapi berubahlah oleh pembaharuan budimu, sehingga kamu dapat membedakan manakah kehendak Allah: apa yang baik, yang berkenan kepada Allah dan yang sempurna” (Rm. 12:2).

\section{Menerima Makanan Keras}

Kedewasaan rohani sangat dibutuhkan oleh orang Kristen agar kehidupan mereka sungguh mendemonstrasikan karakter Kristus. Orang percaya yang dewasa rohani akan memiliki iman yang kokoh di tengah gencarnya serangan pengaruh pengajaran yang menyesatkan dan di tengah berbagai hantaman badai kehidupan. ${ }^{36}$ Untuk bisa bertumbuh menjadi dewasa dalam kerohanian orang percaya sudah tidak membutuhkan susu tetapi makanan keras, makanan keras yang dapat memberikan energi lebih bagi aktivitas kerohanian sehingga dapat menghasilkan buah kebenaran yang memberikan damai sejahtera kepada sesama dan terlebih orang percaya semakin serupa dengan Kristus (Ibr 12:11).

Dalam 1 Korintus 3:2 tidak dewasa dalam Kritus menerangkan sebutan yang terakhir sebagai népios, sedangkan sebutan sebagai orang yang bersifat daging (sarkinos) dan diungkapkan lagi oleh Paulus dalam 1 Korintus 3:3-4. Hal itu mengingat kehidupan kerohanian jemaat Korintus adalah bayi rohani di dalam Kristus, maka Paulus tidak dapat memberikan makanan keras kepada jemaat Korintus dan hanya diberikan susu (1 Kor 3:2a). Karena Paulus tahu akan kehidupan kerohanian jemaat Korintus. Bahwa dari dulu jemaat Korintus hanya siap menerima pengajaran-pengajaran dasar Kristen, bukan yang bersifat lanjutan (Ibr 5:11-14). Dari sejak awal pelayanan di Korintus Paulus hanya bisa menyampaikan ajaran-ajaran dasar kekristenan. Dengan demikian, 1 Kor 3:1-2 dipahami sebagai teguran dan nasehat supaya mereka mengganti jenis makanan rohani mereka.

\footnotetext{
${ }^{34}$ Sabdono, Tanggung Jawab Memiliki Keselamatan.

${ }^{35}$ Erastus Sabdono, Hidup Menurut Roh (Jakarta: Rehobat Literatur, 2018), 71.

${ }^{36}$ Gunawan, "Pemuridan Dan Kedewasaan Rohani."
} 
Mereka seharusnya sudah menikmati makanan keras, sehingga pertumbuhan rohani dapat menghasilkan pribadi yang tahan dalam menghadapi angin pengajaran sesat maupun kesombongan yang mengultuskan pemimpin rohani. Oleh karena itu mereka tidak dapat memakanan makanan keras sekalipun sudah lama di bawah bimbingan pelayanan Paulus, sebab mereka tidak memperlihatkan kemajuan dalam pengetahuan Kristen mereka. Perhatikanlah, orang-orang Kristen yang tidak berusaha untuk tumbuh dalam kasih karunia dan pengetahuan memang layak untuk ditegur. ${ }^{37}$

\section{Menjadi Pembawa damai}

Rasul Paulus memberikan pesan kepada jemaat Korintus yang tidak dewasa dalam kerohanian dalam memandang sikap perbedaan. Karena, menurut Matthew Hendry, dalam perjalanan rohani jemaat Korintus mengungkapkan adanya roh perpecahan. ${ }^{38}$ Orang percaya di kota Korintus mengabaikan kesatuan, atau mereka tidak mempedulikan saudara seiman. Tidak taat pada ajaran firman dan tidak memperhatikan kesatuan sehingga berdampak pada sikap dan pola pikir yang egois, mementingkan diri sendiri maupun golongan. Paulus menegur mereka karena keduniawian mereka, dan mengungkap perbantahan dan perselisihan mereka mengenai para pelayan sebagai buktinya: Karena kamu masih manusia duniawi. Sebab, jika di antara kamu ada iri hati dan perselisihan bukankah hal itu menunjukkan, bahwa kamu manusia duniawi dan bahwa kamu hidup secara manusiawi? Mereka berseteru, bertikai, dan terpecah-belah mengenai pelayanpelayan, sebab seorang berkata: "Aku dari golongan Paulus," dan yang lain berkata: "Aku dari golongan Apolos." Ini merupakan bukti bahwa mereka masih bersifat duniawi. Sedangkan kepentingan dan kesenangan duniawi sudah mengombang-ambingkan mereka terlalu jauh. Perbantahan dan perselisihan mengenai agama ataupun pemipin merupakan bukti menyedihkan dari keduniawian yang masih tersisa dalam diri untuk menonjolkan kesombongan.

Hal ini yang terjadi dalam jemaat Korintus, seperti Paulus mengungkapkan kepada jemaat tidak dapat berbicara dengan mereka seperti dengan manusia rohani. Hal ini dikarenakan mereka tidak berdiri teguh, mereka tidak hidup berdasarkan pewahyuan Roh Kudus, namun mereka masih di bawah roh kedagingan yang mementingkan nama dan golongan. Paulus dengan jelas bahwa mementingkan golongan adalah bukti bahwa mereka masih manusia duniawi. Berbanding berbalik dengan manusia rohani, mereka yang mau bertumbuh dalam pengenalan akan Tuhan dan menjadi dewasa dalam Kristus, tidak akan terkhamiri oleh orang lain maupun golongan-golongan yang ada disekitarnya. Orang percaya juga harus menempatkan dirinya sebagai satu kesatuan di dalam tubuh Kristus sebagai bagian keluarga dan kewarganegaraan Allah. Dan menganggap apa yang terjadi dalam pelayanan bukan suatu persaingan atau pertandingan melainkan mengarah kepada kesatuan sebagai tubuh Kristus yang saling melengkapi, tterlebih memfokuskan diri kepada

\footnotetext{
${ }^{37}$ Henry’s Matthew, "Matthew Henry Commentary On Whole Bible," 2002, https://www.biblestudytools.com/commentaries/matthew-henry-complete/1 Korintus /2.html.

${ }^{38}$ Henry's Matthew, "Matthew Henry Commentary On Whole Bible," 2002, https://www.biblestudytools.com/commentaries/matthew-henry-complete/1 Korintus/2.html.
} 
apa yang diinginkan Tuhan secara personal maupun global dengan adanya energi dari kesatuan yang saling bergandengan tangan. Karena sejatinya orang percaya yang memiliki kerohanian yang dewasa dapat menjadi terang dan garam dalam lingkungan walaupun banyak perbedaan.

Melihat dampak-dampak negatif yang ditimbulkan oleh orang Kristen yang tidak dewasa secara rohani, maka adalah suatu keharusan bagi orang Kristen untuk mengalami kedewasaan rohani. Hal ini dilakukan agar kehidupan mereka tidak menjadi sumber masalah dalam gereja, menimbulkan konflik dalam gereja, namun mau giat terlibat dalam pekerjaan Tuhan, sehingga hidupnya menjadi kesaksian yang hidup dan menjadi berkat bagi orang lain. Maka dari itu, orang percaya sebagai bagian dari anggota gereja perlu diajar dan dibina agar bertumbuh menuju kedewasaan rohani. Beberapa tanda dari seseorang yang sudah dewasa rohani, diantaranya: tanda pertama, memiliki pengetahuan yang benar tentang firman Tuhan. Oleh sebab itu, orang Kristen harus memiliki kedewasaan rohani agar mampu menciptakan kerukunan dan kedamaian yang indah di dalam gereja. Dengan demikian gereja akan menjadi tempat yang disenangi oleh banyak orang sehingga mereka tertarik untuk datang ke rumah Tuhan. Seperti yang dinyatakan oleh Yesus bahwa berbahagialah orang yang membawa damai karena mereka akan disebut anak-anak Allah (Mat. 5:9) Membawa damai adalah perbuatan yang dilakukan untuk menyelesaikan masalah-masalah yang sedang dihadapi supaya persoalannya selesai.

\section{Kesimpulan}

Dengan demikian dapat disimpulkan bahwa manusia duniawi dapat menimbulkan berbagai macam persoalan dan pertikaian yang dapat mengancam keberlangsungan iman secara persoanal maupun pandangan yang buruk terhadap kekristenan. Manusia duniawi dapat menjadi pemicu iri hati sehingga terjadi pertengkaran dan perselisihan karena pola pikir dan pengenalan akan Tuhan tidak menjadi prioritas dalam hidupnya. Ketidakdewasaan dalam berpikir dan bertindak menjadikan pribadi bersifat kekanak-kanakan, tidak dapat membawa terang dan garam di tengah kehidupan orang percaya, bahkan bagi mata orang yang belum mengenal Allah. Karakteristik manusia duniawi yang mengacu pada belum dewasa dalam Kristus, dan makanannya masih sebatas susu, serta memiliki sikap iri hati, perselisihan dan hidup secara duniawi. Sementara sifat manusia rohani dalam Yesus Kristus memiliki rciri meninggalkan sifat kanak-kanak, menerima makanan keras dan menjadi pembawa damai. Sehingga, dapat diharapkan manusia rohani harus terus bertumbuh dan memiliki kesadaran untuk berubah dalam segala hal yang baik agar manusia rohani dapat bermanfaat dan memberikan buah yang baik bagi kehidupan orang percaya masa kini

\section{Referensi}

Arifianto, Yonatan Alex, and Asih sumiwi Rachmani. "Peran Roh Kudus Dalam Menuntun Orang Percaya Kepada Seluruh Kebenaran Berdasarkan Yohanes 16 : 13.” Jurnal Diegesis 3, no. 1 (2020): 1-12.

Daulany, Richard, and Rahel Daulany. Firman Hidup 70. Jakarta: BPK Gunung Mulia, 2008. 
Denney, Andrew S., and Richard Tewksbury. "How to Write a Literature Review." Journal of Criminal Justice Education 24, no. 2 (2013): 218-34. https://doi.org/10.1080/10511253.2012.730617.

Drane, John. Mamahami Perjanjian Baru Pengantar Historis Teologis. Jakarta: BPK Gunung Mulia, 2016.

Drewes, B.F., Wilfrid Haubeck, and Siebenthal Heinrich Von. Kunci Bahasa Yunani Perjanjian Baru Surat Roma Hingga Kitab Wahyu, Jakarta: BPK Gunung Mulia, 2011.

Gunawan, Agung. "Pemuridan Dan Kedewasaan Rohani." Jurnal Theologia Aletheia, 2017.

Gunawan, Djohan. Roh Inspirasi Anda Agar Hidup Dan Usaha Lebih Sukses. Jakarta: Elex Media Komputindo, 2014.

Guthrie, Donald. Teologi Perjanjian Baru 1. Jakarta: BPK Gunung Mulia, 2008.

Hadiwijono, Harun. Iman Kristen. Jakarta: BPK Gunung Mulia, 1992.

Henry’s Matthew. "Matthew Henry Commentary On Whole Bible," 2002.

https://www.biblestudytools.com/commentaries/matthew-henry-complete/1

Timotius/2.html.

Heward, Dag. Pengaruh Manis Dari Pengurapan. mill, 2018.

Milne, Bruce. Mengenal Kebenaran. Jakarta: BPK Gunung Mulia, 2009.

Nee, Watchman. Manusia Rohani 2. Surabaya: Yasperin, 2019.

Orles. "Efektifitas Pemuridan KEKAL Dalam Membimbing Gereja Menuju Kedewasaan Rohani.” HUPEERETÉS Jurnal Teologi Dan Pendidikan Kristen 1, no. 2 (2020): $118-29$.

Pfitzner, V.C. Kesatuan Dalam Kepelbagaian : Ulasan Atas 1 Korintus. Malang: Gandum Mas, 2006.

Piper, John. Sukacita Ekspositori. Surabaya: Literatur Perkantas, 2020.

Sabdono, Erastus. Hidup Menurut Roh. Jakarta: Rehobat Literatur, 2018.

—. Makna Sejati Pentakosta. Jakarta: Literatur Perkantas, 2019. . Tanggung Jawab Memiliki Keselamatan. Jakarta: Rehobat Literatur, 2020.

Siregar, Jundo Parasian. "Pengembangan Watak Kristen Melalui Pengampunan." Imanuel Jurnal Teologi Dan Pendidikan Kristen 1, no. 1 (2020): 33-43.

Sproul, R.C. Kebenaran-Kebenaran Dasar Iman Kristen. Malang: Literatur SAAT, 2018.

Stamp, Donald c. Alkitab Hidup Berkelimpahan. Malang: gandum mas, 1994.

Telaumbanua, Arozatulo. "Peran Gembala Sidang Sebagai Pendidik Dalam Pertumbuhan Rohani Jemaat.” FIDEI: Jurnal Teologi Sistematika Dan Praktika, 2019. https://doi.org/10.34081/fidei.v2i2.45.

Tong, Stephen. From Faith To Faith, Dari Iman Kepada Iman. Surabaya: Momentum, 2013.

White, Jerry. Kejujuran, Moral Dan Hati Nurani. Jakarta: BPK Gunung Mulia, 2004.

Wijiati, Maria. "Konseling Patoral Sebagai Sarana Dalam Membentuk Keluarga Kristen Masa Kini." Pneumatikos 6, no. 1 (2018): 2-55.

Wilkinson, Bruce, and Boa Kenneth. Talk Thru The Bible. Malang: Gandum Mas, 2017.

Yanti, M E. "Integritas Dalam Peribadatan Menurut Amos 4: 4-5." IMMANUEL: Jurnal Teologi Dan Pendidikan Kristen, 2020.

Zaluchu, Sonny Eli. "Strategi Penelitian Kualitatif Dan Kuantitatif Di Dalam Penelitian Agama." Evangelikal: Jurnal Teologi Injili Dan Pembinaan Warga Jemaat, 2020. https://doi.org/10.46445/ejti.v4i1.167.

Zuck Roy B. A Biblical Teologi Of The Old Testament. Malang: Gandum Mas, 2015. 